\title{
Monitoring agricultural ecosystems by using wild bees as environmental indicators
}

\author{
Matthias Schindler', Olaf Diestelhorst ${ }^{2}$, Stephan Härtel ${ }^{3}$, Christoph Saure ${ }^{4}$, \\ Arno Schanowski ${ }^{5}$, Hans R. Schwenninger ${ }^{6}$
}

I University of Bonn, INRES, Dep. Ecology of Cultural Landscape, Melbweg 42, D-53127 Bonn 2 University of Düsseldorf, Institute of Sensory Ecology, Universitätsstraße 1, D-40225 Düsseldorf 3 University of Würzburg, Dep. of Animal Ecology and Tropical Biology, Am Hubland, D-97074 Würzburg 4 Büro für tierökologische Studien, Birkbuschstraße 62, D-12167 Berlin 5 Lilienstraße 6, 77880 Sasbach 6 Büro Entomologie + Ökologie, Goslarer Str. 53, D-70499 Stuttgart

Corresponding author: Matthias Schindler (m.schindler@uni-bonn.de)

Academic editor: J. Settele | Received 27 June 2012 | Accepted 2 January 2013 | Published 8 August 2013

Citation: Schindler M, Diestelhorst O, Härtel S, Saure C, Schanowski A, Schwenninger HR (2013) Monitoring agricultural ecosystems by using wild bees as environmental indicators. BioRisk 8: 53-71. doi: 10.3897/biorisk.8.3600

\begin{abstract}
Wild bees are abundant in agricultural ecosystems and contribute significantly to the pollination of many crops. The specialisation of many wild bees on particular nesting sites and food resources makes them sensitive to changing habitat conditions. Therefore wild bees are important indicators for environmental impact assessments. Long-term monitoring schemes to measure changes of wild bee communities in agricultural ecosystems are currently lacking. Here we suggest a highly standardized monitoring approach which combines transect walks and pan traps (bowls). The combination of these two methods provides high sample coverage and reveals data on plant-pollinator interactions. We point out that comprehensive methodical, biological and taxonomical expertise is mandatory. The suggested approach is applicable to diverse monitoring goals in an agricultural context e.g. the impact of land use changes as well as monitoring potential effects of GM crops on wild bees.
\end{abstract}

\section{Keywords}

Wild bees, standardised ecological assessment, agricultural ecosystems, GMO monitoring

Copyright Matthias Schindler et al. This is an open access article distributed under the terms of the Creative Commons Attribution License 3.0 (CC-BY), which permits unrestricted use, distribution, and reproduction in any medium, provided the original author and source are credited. 


\section{Introduction}

There are more than 2000 species of bee in Europe (Fauna Europaea 2011), with a gradient in bee species diversity from the south (high) to the north (low) and from the east (high) to the west (low). This gradient is caused mainly by the climatic requirements of bees; most bee species are associated with sunny and warm locations (Westrich 1989, Michener 2007). About 750 bee species are found in Central Europe (Amiet and Krebs 2012).

Bees have a keystone function in ecosystems (see Kratochwil 2003). Pollination by bees is essential for the reproduction of many wild plants. In agricultural ecosystems, bees contribute to the pollination of many crops (Roubik 1995, Allen-Wardell et al. 1998, Buchmann and Asher 2005) and a correlation between bee diversity and the ecosystem service of pollination in agroecosystems has been demonstrated in several studies (reviewed in Ricketts et al. 2008). Pollination increases the yield and the quality of many agricultural field crops. A decline of bees could result in a reduced diversity of insect pollinated plants (reviewed in Klein et al. 2007). Moreover pollination of certain fruits can increase their micronutrient content (Eilers et al. 2011). In Europe the value of insect pollination has recently been estimated at 15 billion Euros per annum (European Commission 2011).

Bee species other than the domesticated honey bee are regarded as wild bees. Many species of wild bees are highly specialized on particular nesting sites and food resources (see Westrich 1996, Michener 2007). Thus wild bees are highly sensitive to anthropogenically driven habitat degradation and habitat fragmentation (reviewed in Brown and Paxton 2009). Many wild bee species are considered as good indicators to evaluate the conservation status of open landscape biotopes (e.g. Schwenninger 1992, Schmid-Egger 1994, Tscharntke et al. 1998, Plachter et al. 2002, Sepp et al. 2004, Jauker et al. 2009).

\section{Life history traits of bees}

Wild bees show a huge diversity of life history characteristics (Westrich 1989, Murray et al. 2009). They can be grouped in accordance to their degree of ecological specialisation:

\section{Nesting}

About 50 percent of all bee species nest in a burrow in the ground (e.g. sand bees [Andrena], sweat bees [Halictus/ Lasioglossum]), favouring south facing banks and sparsely vegetated areas. Other bees nest in cavities such as borings in dead wood, small holes in walls or empty snail shells (e.g. mason bees [Osmia] or leafcutter bees [Megachile]) or use old mouse nests or other cavities in the ground (e.g. bumblebees $[$ Bombus $]$ ). 


\section{Foraging}

Adult bees generally use flowers of diverse plant species as nectar sources. Bee larvae develop on a diet of pollen and nectar (in Europe, only larvae of the genus Macropis are known to use floral oils as a substitute for nectar). The adult females provide their brood cells with a mix of pollen and nectar. Polylectic species are able to use pollen from a wide range of different plant families. In contrast, about 35 percent of the bees in Central Europe - the so called oligolectic bees - are highly specialized, collecting pollen only from certain closely related plant species (Zurbuchen and Müller 2012).

\section{Life cycle and sociality}

More than 80 percent of European bee species are solitary. Females of these bees construct their own nests and provide food for their offspring themselves. Adult females usually only live for 4 to 6 weeks. In contrast, eusocial bees live in colonies. In Europe most bumblebees and many sweat bees are primitively eusocial. Their annual colonies are usually founded by a single queen. Queens of the eusocial sweat bee Lasioglossum marginatum live for 5 years. The only so-called complex eusocial bee species in Europe is the honey bee Apis mellifera; queens live up to 5 years, whereupon the colony's old queen is replaced by a daughter queen i.e. the colony is perennial.

\section{Cuckoo bees}

About $25 \%$ of European bee species use the nests and provisions of a host bee species for their reproduction. These cleptoparasites ("cuckoo bees") are usually associated with specific host species. Female parasites lay their eggs in the brood cells constructed and provisioned by the host female. In the case of parasites of social hosts, parasite females take over both host colonies and host workers. Usually parasite females kill the host queen. Thereafter the eggs, larvae and offspring of the social parasite are provisioned by the workers of the original host queen.

\section{Wild bees in agricultural ecosystems}

Until the beginning of the 20th century, extensive farming practices such as threefield crop rotation shaped landscapes and created diverse habitat mosaics. As a result of the industrial revolution, historical forms of land use changed rapidly (e.g. Kaule 1991, Plachter 1991, Benton et al. 2003). The intensification of agriculture reduced the availability of foraging habitats and nesting sites for bees. For example, in arable regions, the loss of non-cropped areas and Fabaceae-rich grassland as well as the tendency to rotation crops lacking flowering cultivars decreased the habitat quality of these regions for bees (see Williams and Carreck 1994, Goulson et al. 2005, Bommarco et al. 2012). 
Wild bee diversity in arable landscapes is affected by the spatial and temporal availability of food sources and the presence of suitable nesting sites (e.g. Banaszak 1996, Steffan-Dewenter 1998, Tscharntke et al. 2005, Holzschuh et al. 2007). Landscapescale factors as well as field scale factors likely influence the composition of bee communities in such ecosystems (Fig. 1).

For example non-crop habitats in the vicinity of farm sites can increase the species richness and abundance of bees (e.g. Kremen et al. 2004). Farming practices such as weed control and tillage as well as crop rotation influence the quality of arable fields as bee foraging sites or nesting habitats. Several studies indicate a positive impact of e.g. fallows or certain flowering crops on bee diversity (Schwenninger 1992, Gathmann 1998, Steffan-Dewenter 1998, Herrmann 2000, Saure et al. 2003, Saure and Berger 2006, Berger and Pfeffer 2011, Schindler and Wittmann 2011). However, deteriorating habitat quality and the loss of habitat heterogeneity has led to widespread decrease in bee diversity and bee abundance in agricultural ecosystems. Most bee species need food and nesting resources close to each other since

\section{Bee requisites (=required resources):}

- Food plants (nectar, pollen)

- nesting sites (bare soil, subterranean cavities, hollow stems)

- nesting resources (mud, leaves, resin)

- overwintering sites, mating sites

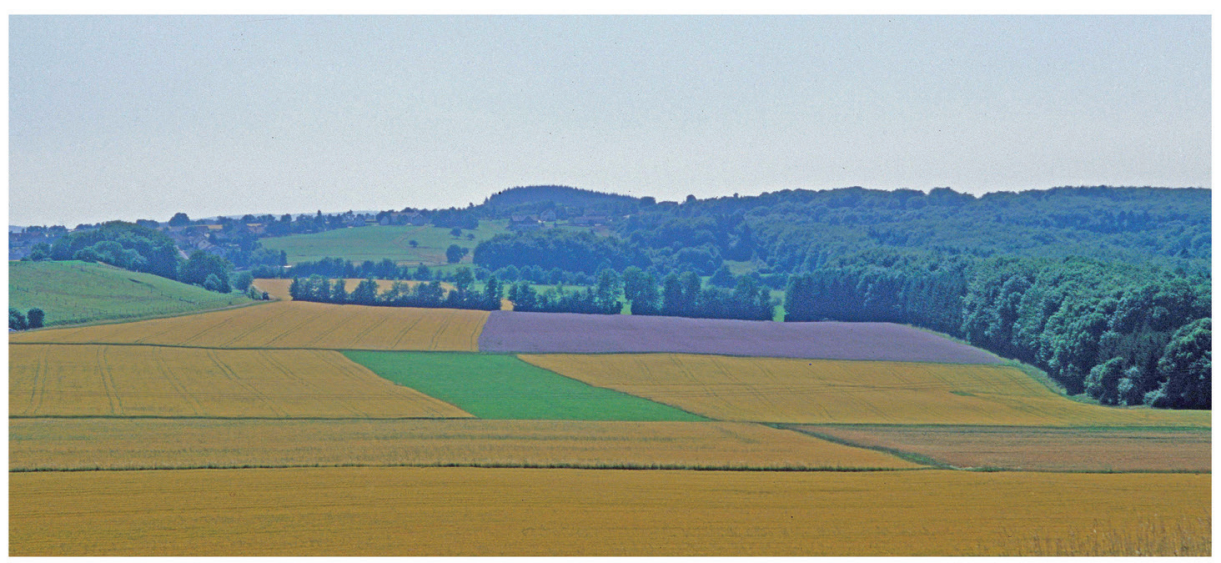

\section{Landscape scale:}

- habitat type (agricultural, non crop area, urban)

- spatial distribution of habitat patches

- size of habitats
Field scale:

- crops and crop rotation

- weed and pest control

- farming practices (tillage)

- field size

Figure I. Factors affecting bee communities in agricultural landscapes (adopted from Kremen 2008). 
they have small activity ranges (Walther-Hellwig and Frankl 2000, Gathmann and Tscharntke 2002, Greenleaf et al. 2007, Zurbuchen et al. 2010b). For this reason, the spatial and temporal availability of the resources can markedly affect the rate of reproduction of bees (see Zurbuchen et al. 2010 a).

An analysis of 23 studies of wild bee communities across different agricultural landscapes in Central Europe revealed a total of 293 bee species (Saure et al. unpublished). Only 54 of these bee species were found in more than 10 studies (see Table 1). These species are predominantly generalists (examples are shown in Fig. 2). According to the Red Data List of Germany, only three species (Andrena pilipes agg., Lasioglossum quadrinotatum, Bombus ruderarius) are endangered (Westrich et al. 2012), two species (Colletes daviesanus, Melitta leporina) demonstrate floral specialisation.

\section{GM crop effects on bees}

Commercialized genetically modified (GM) crops could affect bee communities in two different ways, directly and indirectly (Table 2). GM crops carrying herbicide resistance (HR) and crops expressing insecticidal proteins derived from the bacterium Bacillus thuringiensis (Bt) are the most cultivated GM crops worldwide (James 2010). Across a number of studies on honey bees, direct insecticidal influence of Bt-crops has never been reported (Duan et al. 2008). These reports of non-toxicity are consistent with risk assessment data of Bt-crops on social and solitary wild bees (Malone and

Table I. Number of bee species in agricultural landscapes (according to 23 evaluated studies, Saure et al. unpublished).

\begin{tabular}{l|c|c|c|c}
\hline Taxonomic range & $\begin{array}{c}\text { Infrequent } \\
(\mathbf{1 - 4} \text { mentions })\end{array}$ & $\begin{array}{c}\text { Occasional } \\
(\mathbf{5 - 9} \text { mentions })\end{array}$ & $\begin{array}{c}\text { Frequent } \\
(\mathbf{1 0 - 2 3} \text { mentions })\end{array}$ & Total \\
\hline Colletidae & 15 & 9 & 2 & 26 \\
\hline Halictidae & 41 & 18 & 18 & 77 \\
\hline Andrenidae & 31 & 18 & 18 & 67 \\
\hline Melittidae & 5 & 1 & 1 & 7 \\
\hline Megachilidae & 33 & 12 & 1 & 46 \\
\hline Apidae & 36 & 20 & 14 & 70 \\
\hline total & $161(55 \%)$ & $78(27 \%)$ & $54(18 \%)$ & $293(100 \%)$ \\
\hline
\end{tabular}

Table 2. Categories of potential effects of genetically modified crops on bees (reviewed in Morandin 2008).

\begin{tabular}{l|l}
\hline Direct toxic effects & Indirect agroecosystem effects \\
\hline $\begin{array}{l}\text { Toxicity of proteins expressed by the } \\
\text { inserted gene on bees. Effects can } \\
\text { lead to modified behaviour of bees } \\
\text { or can be sublethal or lethal. }\end{array}$ & $\begin{array}{l}\text { Unintentional alteration of the modified plant or differences in } \\
\text { agricultural practices associated with the GM cultivar. }\end{array}$ \\
$\begin{array}{l}\text { Effects on the quality or attractiveness of foraging plants by } \\
\text { altering the phenotype or physiology of the plant. } \\
\text { Effects on the foraging habitat by decreased weed abundance } \\
\text { in and around the GM fields. }\end{array}$ \\
\hline
\end{tabular}



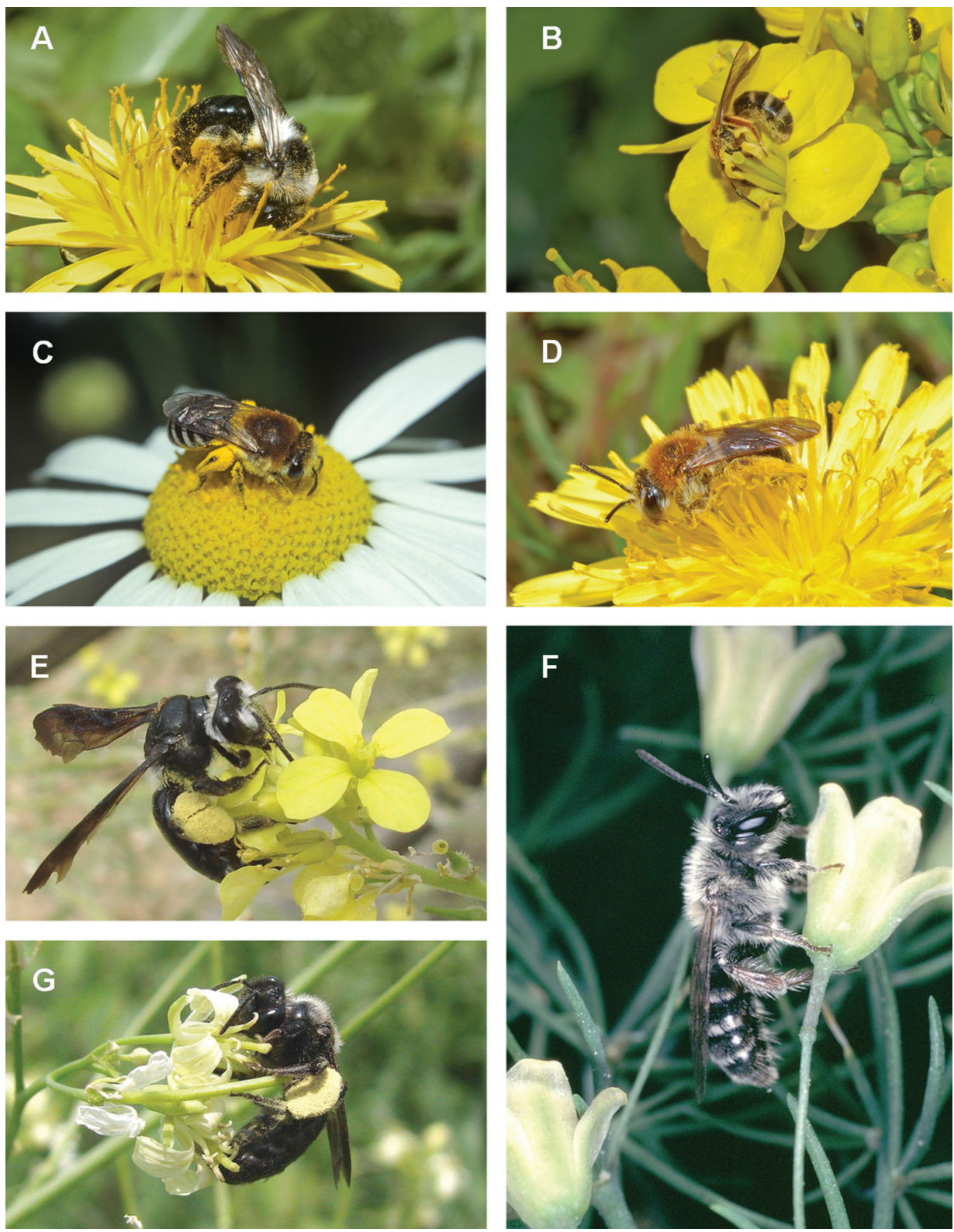

Figure 2. Wild bee species which can be found in agricultural landscapes. A Andrena cineraria (frequent) B Lasioglossum calceatum (frequent) C Colletes daviesanus (frequent) D Andrena haemorrhoa (frequent) E Andrena agilissima (infrequent) F Andrena chrysopus (infrequent) G Andrena nigrospina (occasional). Fotos: A, B, C, D: Schindler; E, G: Diestelhorst; F: Schwenninger.

Burgess 2009). Nevertheless, only few studies address direct toxicity effects on this group of pollinators. Exposed bumblebee colonies (Bombus impatiens, B. occidentalis, $B$. terrestris) did not display any effect of insecticidal Bt treatment (lethal or suble- 
thal) (Morandin and Winston 2003; Malone et al. 2007; Babendreier et al. 2008). Konrad et al. $(2008,2009)$ did not find adverse effects of purified Bt-toxin (Cry1Ab) on life history parameters and on the longevity of the solitary bee Osmia bicornis. Currently, there are no indications that commercialized Bt-crops pose a direct risk to bees. Nevertheless, new GM varieties have to be tested for direct effects on honeybees and wild bees.

Indirect effects of HR crops on bee diversity are most likely to occur. Only very few studies have compared agroecosystems having GM crops to other cropping systems in terms of their effects on wild bee populations. Different cropping methods associated with certain cropping systems such as field size and pesticide use may affect wild bee abundance (Morandin and Winston 2005). Effective weed control through the application of broad-spectrum herbicides in HR cropping systems is suggested as a main factor influencing bee abundance (see Haughton et al. 2003, Hawes et al. 2003). Indeed, food resource availability plays a central role in regulating wild bee populations (Roulston and Goodell 2011). Consequently, indirect effects of HR cropping systems on wild bees, including the application of broad-spectrum herbicides, should be tested in GMO monitoring schemes.

\section{Standardised monitoring of wild bees}

Entomologists have established numerous methods to monitor flower-visiting insects such as bees, and several standardized methodical approaches have been developed (Table 3). A general description of methods has been published by e.g. Mühlenberg (1993), Duelli et al. (1999) and Sutherland (2010). Schwenninger (1994) and Weber

Table 3. Common field ecological methods to survey bee diversity and abundance (adopted from Steyskal et al. 1986 and Sutherland 2010).

\begin{tabular}{l|l}
\hline & Description of the method \\
\hline $\begin{array}{l}\text { Sightings/ collecting } \\
\text { with insect nets }\end{array}$ & $\begin{array}{l}\text { Direct searching of bees e.g. at nesting sites or forage plants. This can be done } \\
\text { by standardizing the area and/or the level of sampling effort. Bees are collected } \\
\text { with insect nets. }\end{array}$ \\
\hline Malaise traps & $\begin{array}{l}\text { Malaise traps are made out of fine netting with vertical black screens and } \\
\text { a bright sloping roof that leads to a collecting device (e.g. a jar filled with } \\
\text { conserving agent). Flying bees hit the screen and walk upwards. Positive } \\
\text { phototaxis (response to a light stimulus) of bees leads them to the bright roof } \\
\text { and finally to the jar. }\end{array}$ \\
\hline $\begin{array}{l}\text { Window traps } \\
\text { (Interception traps) }\end{array}$ & $\begin{array}{l}\text { Window (acrylic glass) traps collect bees on the wing. Bee specimens fly into } \\
\text { the window and drop into a bowl with water or with a liquid conserving agent. }\end{array}$ \\
\hline $\begin{array}{l}\text { Pan traps } \\
\text { (Water traps, }\end{array}$ & $\begin{array}{l}\text { Bee specimens fly into a pan or bowl with water or with a liquid conserving } \\
\text { agent. The spectral properties of pan traps attract bees: yellow, white and } \\
\text { blue pan traps are most suitable whilst UV-reflective surfaces enhance their } \\
\text { attractiveness for bees. }\end{array}$ \\
\hline
\end{tabular}


(1999) published detailed methodical specifications concerning inventory studies on wild bees. Westphal et al. (2008) discussed methods, which have been used to assess pollinator diversity and abundance.

Standardised monitoring of wild bees requires a methodological design which ensures a high sample coverage but minimizes significant negative impacts on population sizes of individual bee species. Monitoring collaborators should be highly familiar with the taxonomy, biology and ecology of bees. Furthermore basic knowledge of botany and methodical approaches for bee collection are essential.

\section{Methodical approach for monitoring of bees}

Field studies relating to bee-monitoring preferably should be conducted for at least 3 years. To correct for temporal dynamics of wild bee populations across multiple years, the monitoring year must be regarded as random factor in the statistical analysis. In search of the most suitable methods for the monitoring of wild bees, one has to consider that negative effects of the studies on bee populations must be minimized.

For the monitoring of bees, we suggest a combination of sightings and collecting with insect nets along transect walks and short-term collecting with pan traps (max. one day). The use of temporarily positioned pan traps as a supplementary method may improve the results (see Meissle et al. 2012).

\section{Study design}

In each study area, adequate unploughed strips should be identified as study sites. On the unploughed strips at least 4 transects with a total length of $1000 \mathrm{~m}$ and width of 1 $\mathrm{m}$ should be defined. Transects should be established at representative strips within a radius (buffer) of $500 \mathrm{~m}$ from the borders of the target fields.

Next to each monitoring site, a 'control' or reference site should be identified at a minimum distance of 4 to 5 kilometres. This distance prevents overlapping of foraging ranges from monitoring to control site for e.g. bumblebees; some bumblebee species fly distances up to 2.5 kilometres (Walther-Hellwig and Frankl 2000, Hagen et al. 2011). The reference site should be situated in the vicinity of the study area. Landscape characteristics, farming practices as well as abiotic parameters in the reference site should be consistent with the study area. The choice of and sampling at transects should be conducted in the same way as in the study area. In cases where there are two observers per study, the observer of the study area must swap with the observers of the reference area and vice versa to avoid systematic monitoring biases. The advocated design, a paired design, allows for variation across large geographic distances for inherent differences in bee species diversity and bee abundance due, for example, to climate. A non-paired design would also be suitable, but at the cost of reduced statistical power; considerably greater number of sites would be required 
in a non-paired design to allow the effects of geography on bee species diversity and bee abundance to be partitioned out of a multivariate analysis of the impact of a specific anthropogenic factor (e.g. pesticide use) on wild bee communities (see Lang and Bühler 2012).

\section{Sampling of wild bees}

The flight periods of bees are synchronised with the growing season of plants. Therefore field studies should be conducted monthly from mid-March to mid-September. The beginning of the sampling period can vary depending on the climatic conditions in different regions or years.

In March and April transect walks (50 minutes / $250 \mathrm{~m}$ ) should be conducted between 10:00 a.m. and 4:00 p.m. In May-September transect walks (50 minutes/ $250 \mathrm{~m}$ ) should be carried out both in the morning and in the afternoon between 9:00 a.m. and 5:00 p.m. Studies should be conducted only on sunny and windless days. Sampling should be repeated six times per year (every 3-4 weeks) at each study site. For each study site, the schedule and defined habitat parameters such as habitat type, abundance of habitats and size of habitats should be accurately documented on a standardised field report.

Bee specimens that can be identified directly in the field without catching should be registered in the field report. Those specimens that are difficult to distinguish should be collected with an insect net and stored in clear vials in a dark bag chilled with an ice package. Each vial should be labelled (e.g. location, date, time, number of the transect, host plant). At the end of the transect walks, bees collected in vials should be determined. Identified specimens should be documented by a macro photo as a voucher before they are released. Unidentified wild bees should be exposed to ethyl acetate fumes. If DNA analysis (e.g. DNA barcoding) is necessary to identify specimens, bees should be exposed to ethyl acetate as short as possible in order to prevent degradation of the DNA (see Magnacca and Brown 2012).

Before starting with the transect walks, one set of three UV reflective pan traps (yellow, blue, white) (Stephen and Rao 2005, Droege 2006) should be positioned in one representative transect at the level of the surrounding vegetation. The outer casing of the pan traps generally should be black to prevent attracting bees over a great distance. Pan traps should be filled with water and a drop of unscented detergent should be added as wetting agent. The pan traps should be removed at the end of the examination day.

The described method should also be used on crops that are potential foraging habitats for wild bees. A minimum of three surveys should be conducted during the crop flowering period. Pan traps should be positioned within the crop field and preferably at the same height as flowers of the crop. The distance of the pan traps to the field boundary should be at least $5 \mathrm{~m}$ to prevent attracting bees from non-crop areas (Droege et al. 2010).

All collected bee specimens should be pinned with stainless steel insect pins. Wild bees should be prepared as described in Ebmer (2010). Voucher specimens should be 
preserved in close-fitting insect boxes. Samples for DNA analysis should be stored under cool conditions (e.g. a domestic fridge, $+4^{\circ} \mathrm{C}$ ) in $\geq 95 \%$ ethanol.

Analysis should be made by comparing the variables species diversity and species abundance of the anthropogenically altered sites (e.g. GMO monitoring sites) with their paired control sites (e.g. GMO-free monitoring sites). The variance in count data may be addressed by either incorporating a comparison between e.g. GMO and e.g. non-GMO sites in the monitoring design or by analyzing additional data on the relevant environmental context (Lang and Bühler 2012). A recent study corroborates local environmental factors such as habitat type, nesting resources and grazing regime as powerful determinants of community composition in bees (Murray et al. 2012).

\section{Environmental monitoring with wild bees in agro-ecosystems}

Environmental assessments with biotic indicators are carried out to detect changes or predict the potential effects of a given practice or stressor on a specific group of organisms. Indicators must respond to the practice or measure being addressed and the localities for which they must be valid (Osinski et al. 2003).

Wild bees are well-accepted biological indicators, especially for ecological assessment in open landscapes such as arable regions or grasslands (see Schwenninger 1994, Kevan 1999, Weber 1999, Plachter et al. 2002). So far, however, the inclusion of bees in environmental risk assessment is restricted to honey bees and, in a few cases, to bumblebees (Kevan et al. 2008, Romeis et al. 2008). Particularly honey bees have often used as non-target organisms to test the impacts of pesticides (Thompson 2003). Quite recently new rearing methods for honey bee larvae have been developed to test e.g. the effect of pesticides or the impact of GM crop pollen on bee larvae (Hendriksma et al. 2011a, b).

Only few studies deal with the impact of pesticides on wild bees (e.g. Gretenkord 1997, Ladurner et al. 2005, Whitehorn et al. 2012) but no agreed risk assessment procedures for them have yet been established. These laboratory methods are part of a standardized risk assessment, which examines toxicity as a direct effect of an agent to bees. The potential effects of a pesticide at the level of the bee community have almost remained unconsidered (Morandin and Winston 2005, Holzschuh et al. 2008). Tuell and Isaacs (2010) tested a method to compare pest management programs for their potential effect on wild bee communities. So far, however, we lack studies dealing with the indirect effects of environmental stressors on wild bee communities as well as descriptions of standardized methods for long-term studies to measure changes of wild bee communities in agricultural landscapes.

\section{Standardized ecological assessment with wild bees}

The use of wild bees in ecological assessment makes it necessary to develop standardized methods and a precise study design. It must be considered that studies have 
to produce verifiable and reproducible results. For environmental assessment projects with wild bees we recommend the combination of transect walks and pan traps (see section 2). This method is likely to deliver reliable results on the diversity of wild bee communities and the abundance of wild bee species. Particularly for long-term studies, our methodical design provides the following advantages:

- Live observation of bees in combination with net collecting reduces the percentage of killed individuals to $<30 \%$ of the recorded specimens (Schwenninger unpubl.). This approach helps to minimize negative effects of monitoring on bee populations.

- The combination of transect walks and pan traps (bowls) provides high sample coverage. Since pan traps are used only temporarily, their impact on size and composition of bee populations is negligible.

The suggested method can operate efficiently in a wide range of ecological monitoring schemes in agricultural ecosystems. We point out that comprehensive methodical, biological and taxonomical expertise is required. We disagree with Westphal et al. (2008), who, for long-term monitoring schemes, recommend pantraps as the most suitable method for surveyors with different levels of bee taxonomic expertise. It should be considered that long term exposed pan traps are very effective at trapping bees and could negatively influence local bee populations. For this reason we reject long term passive sampling methods. We regard the combination of temporarily located pan traps with standardized transect walks as most suitable for pollinator monitoring schemes. Nevertheless, the implementation of transect walks makes training courses mandatory.

\section{GMO monitoring with wild bees}

The EU directive 2001/18 EC on the deliberate release of genetically modified crops into the environment requires a pre-release environmental risk assessment. Since it is not possible to assess all adverse effects during the pre-release risk assessment, GMO-monitoring is required (Meier and Hilbeck 2005). In the context of nature conservation, the effects of GMOs on biodiversity are of importance. The assessment of changes in biodiversity requires suitable indicator species as well as practical sampling designs. Wild bees meet all requirements as suitable indicators for GMO monitoring (see Table 4). Therefore we strongly recommend a standardized long term monitoring scheme for wild bees.

Table 4. Criteria for the identification of organisms as suitable indicators for GMO monitoring (based on Meier and Hilbeck 2005).

- The indicator species must interact directly or indirectly with a certain GMO.

- The indicator species should be distributed across a large geographic area.

- The indicator species should be abundant.

- The indicator species should be relevant with regard to important ecological processes and functions. 


\section{Conclusions}

There is still a current need for biotic indicators to evaluate the impacts of land use change as well as the effects of agro-environmental schemes on biodiversity (Büchs 2003, Osinski et al. 2003, Bergschmidt 2004, COM 2006). Wild bees are approved bio indicators (Kevan 1999). However, guidelines for standardised ecological assessment by using wild bees are currently missing. Our described methodical design can be applied in many contexts (e.g. impact of land use changes, evaluating ecosystem services, climate change, invasive bee diseases) to different agricultural landscapes in Europe. In future the application of wild bees as biodiversity indicators might also be of relevance in monitoring potential effects of GM crops (see Meier and Hilbeck 2005).

The interpretation of changes in the diversity of wild bee communities and the abundance of certain wild bee species is made difficult because of a lack of former studies in many regions in Germany and Central Europe. Moreover changes of wild bee communities could be attributed e.g. to annual fluctuations in population size, arising from natural variation in population growth, or to the species' dispersal ability (see Murray et al. 2009). Therefore we strongly recommend standardized base-line studies with replications in different agricultural landscapes. Initially the base line should be documented through a three-year field study. Subsequent studies should be repeated every five years to record the status quo and the changes in biodiversity of wild bee communities. Longterm base line monitoring will provide data that allow distinguishing between the natural population dynamics of wild bee species and effects attributed to environmental changes.

An assessment using biotic indicators such as wild bees requires crucial ecological and taxonomic qualifications. Therefore we encourage the establishment of courses to qualify collaborators for our suggested monitoring schemes with wild bees.

\section{Acknowledgements}

We thank two anonymous reviewers for valuable comments on the manuscript. We are grateful to Robert J. Paxton (Halle) who reviewed the English translation and provided valuable comments on the manuscript. Stephan Härtel was supported by the EU project AMIGA (Assessing and Monitoring the Impacts of Genetically modified plants on Agroecosystems). Matthias Schindler was supported by the Ministry for Climate Protection, Environment, Agriculture, Nature Conservation and Consumer Protection of the German State of North Rhine-Westphalia (MKUNLV NRW).

\section{References}

Allen-Wardell G, Bernhardt P, Bitner R, Burquez A, Buchmann S, Cane J, Cox PA, Dalton V, Feinsinger P, Ingram M, Inouye D, Jones CE, Kennedy K, Kevan P, Koopowitz H, 
Medellin R, Medellin-Morales S, Nabhan GP, Pavlik B, Tepedino V, Torchio P, Walker S (1998) The potential consequences of pollinator declines on the conservation of biodiversity and stability of food crop yields. Conservation Biology 12: 8-17. doi: 10.1046/j.15231739.1998.97154.x

Amiet F, Krebs A (2012) Bienen Mitteleuropas. Gattungen, Lebensweise, Beobachtung. Haupt Verlag (Bern): 1-423.

Babendreier D, Reichhart B, Romeis J, Bigler F (2008) Impact of insecticidal proteins expressed in transgenic plants on bumblebee microcolonies. Entomologia Experimentalis et Applicata 126: 148-157. doi: 10.1111/j.1570-7458.2007.00652.x

Banaszak J (1996) Ecological bases of conservation of wild bees. In: Matheson A, Buchmann SL, O’Toole C, Westrich P, Willliams IH (Eds) The Conservation of Bees, Academic Press (London): 55-62.

Benton TG, Vickery JA, Wilson JD (2003) Farmland biodiversity: is habitat heterogeneity the key? Trends in Ecology and Evolution 18: 182-188. doi: 10.1016/S0169-5347(03)00011-9 Berger G, Pfeffer H (2011) Naturschutzbrachen im Ackerbau. Praxishandbuch für die Anlage und optimierte Bewirtschaftung kleinflächiger Lebensräume für die biologische Vielfalt. Verlag Natur \& Text (Rangsdorf): 1-160.

Bergschmidt A (2004) Indikatoren für die internationale und nationale Umweltberichterstattung im Agrarbereich. Landbauforschung Völkenrode Sonderheft, 1-194.

Bommarco R, Lundin O, Smith HG, Rundlöf M (2012) Drastic historic shifts in bumble-bee community composition in Sweden. Proceedings of the Royal Society B: Biological Sciences, 279: 309-315. doi: 10.1098/rspb.2011.0647

Brown MJ, Paxton RJ (2009) The conservation of bees: a global perspective. Apidologie 40: 410-416. doi: 10.1051/apido/2009019

Buchmann SL, Ascher JS (2005) The plight of pollinating bees. Bee World 86: 71-74.

Büchs W (2003) Biodiversity and agri-environmental indicators - general scopes and skills with special reference to the habitat level. Agric. Ecosystems Environ. 98: 35-78. doi: 10.1016/ S0167-8809(03)00070-7

COM (2006) Commission of the European Communities. Development of agri-environmental indicators for monitoring the integration of environmental concerns into the common agricultural policy. COM(2006) 508. SEC(2006) 1136. 1-11.

Droege S (2006) Impact of colour and size of bowl trap on numbers of bees captured. http:// online.sfsu.edu/ - beeplot/pdfs/color\%20and\%20size.pdf

Droege S, Tepedino VJ, Lebhung G, Link W, Minckley RL, Chen Q, Conrad C (2010) Spatial patterns of bee captures in North American bowl trapping surveys. Insect Conservation and Diversity 3: 15-23. doi: 10.1111/j.1752-4598.2009.00074.x

Duan JJ, Marvier M, Huesing J, Dively G, Huang ZY (2008) A meta-analysis of effects of Bt crops on honey bees (Hymenoptera: Apidae). PLoS ONE 3 (1): e1415. doi: 10.1371/ journal.pone.0001415

Duelli P, Obrist MK, Schmatz DR (1999) Biodiversity evaluation in agricultural landscapes: above-ground insects. Agric. Ecosystems Environ. 74: 33-64. doi: 10.1016/S01678809(99)00029-8 
Ebmer AW (2010) Sammeln, Präparieren und Mikroskoptechnik von Wildbienen mit besonderer Berücksichtigung der Furchenbienen (Apoidea, Halictidae). Entomolgica Austriaca 17: 67-82.

Eilers EJ, Kremen C, Smith Greenleaf S, Garber AK, Klein A (2011) Contribution of pollinator-mediated crops to nutrients in the human food supply. PLoS ONE 6 (6): e21363. doi: 10.1371/journal.pone.0021363

European Commission (2011) Communication from the commission to the European Parliament, the council, the economic and social committee and the committee of the regions. Our life insurance, our natural capital: an EU biodiversity strategy to 2020. http:// ec.europa.eu/environment/nature/biodiversity/comm2006/pdf/2020/1_EN_ACT_ part1_v7\%5B1\%5D.pdf

Fauna Europaea (2011) Fauna Europaea version 2.4. Web Service available online at http:// www.faunaeur.org

Gathmann A (1998) Bienen, Wespen und ihre Gegenspieler in der Agrarlandschaft: Artenreichtum und Interaktionen in Nisthilfen, Aktionsradien und Habitatbewertung. Cuvillier Verlag (Göttingen): 1-156.

Gathmann A, Tscharntke T (2002) Foraging ranges of solitary bees. Journal of Animal Ecology 71: 757-764. doi: 10.1046/j.1365-2656.2002.00641.x

Goulson D, Hanley ME, Darvill B, Ellis JS, Knight ME (2005) Causes of rarity in bumblebees. Biological Conservation 122: 1-8. doi: 10.1016/j.biocon.2004.06.017

Greenleaf S, Williams NM, Winfree R, Kremen C (2007) Bee foraging ranges and their relationship to body size. Oecologia 153: 589-596. doi: 10.1007/s00442-007-0752-9

Gretenkord C (1997) Laborzucht der dunklen Erdhummel Bombus terrestris L. (Hymenoptera: Apidae) und toxikologische Untersuchungen unter Labor- und Halbfreilandbedingungen. Verlag Shaker (Aachen): 1-175.

Hagen M, Wikelski M, Kissling WD (2011) Space use of Bumblebees (Bombus spp.) revealed by radio-tracking. PLoS ONE 6 (5): e19997. doi: 10.1371/journal.pone.0019997

Haughton AJ, Champion GT, Hawes C, Heard MS, Brooks DR, Bohan DA, Clark SJ, Dewar AM, Firbank LG, Osborne JL, Perry JN, Rothery P, Roy DB, Scott RJ, Woiwod, IP, Birchall C, Skellern MP, Walker JH, Baker P, Browne EL, Dewar AJG, Garner BH, Haylock LA, Horne SL, Mason NS, Sands RJN, Walker MJ (2003) Invertebrate responses to the management of genetically modified herbicide-tolerant and conventional spring crops. II. Within-field epigeal and aerial arthropods. Philosophical Transactions of the Royal Society of London. Series B: Biological Sciences 358: 1863-1877. doi: 10.1098/ rstb.2003.1408

Hawes C, Haughton AJ, Osborne JL, Roy DB, Clark SJ, Perry JN, Rothery P, Bohan DA, Brooks DR, Champion GT, Dewar AM, Heard MS, Woiwod IP, Daniels RE, Young MW, Parish AM, Scott RJ, Firbank LG, Squire GR (2003) Responses of plants and invertebrate trophic groups to contrasting herbicide regimes in the Farm Scale Evaluations of genetically modified herbicide-tolerant crops. Philosophical Transactions of the Royal Society of London. Series B: Biological Sciences 358: 1899-1913. doi: 10.1098/rstb.2003.1406 
Hendriksma HP, Härtel S, Steffan-Dewenter I (2011a) Honey bee risk assessment: New approaches for in vitro larvae rearing and data analyses. Methods in Ecology and Evolution 2: 509-517. doi: 10.1111/j.2041-210X.2011.00099.x

Hendriksma HP, Härtel S, Steffan-Dewenter I (2011b) Testing pollen of single and stacked insect-resistant Bt-maize on in vitro reared honey bee larvae. PLoS ONE 6(12): e28174. doi: 10.1371/journal.pone.0028174

Herrmann M (2000) Ökologisch-faunistische Untersuchungen an Bienen und Wespen in einer extensiv genutzten Agrarlandschaft (Hymenoptera, Aculeata). Cuvillier Verlag (Göttingen): 1-149.

Holzschuh A, Steffan-Dewenter I, Kleijn D, Tscharntke T (2007) Diversity of flower-visiting bees in cereal fields: effects of farming system, landscape composition and regional context. J. Appl. Ecol. 44: 41-49. doi: 10.1111/j.1365-2664.2006.01259.x

Holzschuh A, Steffan-Dewenter I, Tscharntke T (2008) Agricultural landscapes with organic crops support higher pollinator diversity. Oikos 117: 354-361. doi: 10.1111/j.2007.00301299.16303.x

James C (2010) Global Status of Commercialized Biotech/GM Crops: 2009. ISAAA Brief No. 42. ISAAA: Ithaca, NY.

Jauker F, Diekötter T,Schwarzbach F, Wolters V (2009) Pollinator dispersal in an agricultural matrix: opposing responses of wild bees and hoverflies to landscape structure and distance from main habitat. Landscape Ecology 24: 547-555. doi: 10.1007/s10980-009-9331-2

Kaule G (1991) Arten- und Biotopschutz. Ulmer (Stuttgart): 1-519.

Kevan P (1999) Pollinators as bioindicators of the state of the environment: species, activity and diversity. Agric. Ecosystems Environ. 74: 373-393. doi: 10.1016/S0167-8809(99)00044-4

Kevan P, Kapongo JP, Al-mazra'awi M, Shipp L (2008) Honey bees, bumble bees and biocontrol: new alliances between old friends. In: James RR, Pitts-Singer TL(Eds) Bee pollination in agricultural ecosystems. Oxford University Press (New York.): 65-79.

Klein AM, Vaissière BE, Cane JH, Steffan-Dewenter I, Cunningham SA, Kremen C, Tscharntke $\mathrm{T}$ (2007) Importance of pollinators in changing landscapes for world crops. Proceedings of the Royal Society B: Biological Sciences 274: 303-313. doi: 10.1098/rspb.2006.3721

Konrad R, Connor M, Ferry N, Gatehouse AMR, Babendreier D (2009) Impact of transgenic oilseed rape expressing oryzacystatin-1 (OC-1) and of insecticidal proteins on longevity and digestive enzymes of the solitary bee Osmia bicornis. Journal of Insect Physiology 55 (4): 305-313. doi: 10.1016/j.jinsphys.2008.12.007

Konrad R, Ferry N, Gatehouse AMR, Babendreier D (2008) Potential Effects of Oilseed Rape Expressing Oryzacystatin-1 (OC-1) and of Purified Insecticidal Proteins on Larvae of the Solitary Bee Osmia bicornis. PLOS ONE 3 (7): e2664. doi: 10.1371/journal.pone.0002664

Kratochwil A (2003) Bees (Hymenoptera: Apoidea) as key-stone species: specifics of resources and requisite utilisation in different habitat types. Ber. D. Reinh.-Tüxen-Ges. 15: 59-77.

Kremen C, Williams NM, Bugg, RL, Fay JP, Thorp RW (2004) The area requirements of an ecosystem service: crop pollination by native bee communities in California. Ecology Letters 7: 1109-1119. doi: 10.1111/j.1461-0248.2004.00662.x 
Kremen C (2008) Crop Pollination Services from wild bees. In: James R, Pitts-Singer T (Eds) Bee pollination in agricultural ecosystems. Oxford University Press (New York): 10-26. doi: 10.1093/acprof:oso/9780195316957.003.0002

Ladurner E, Bosch J, Kemp WP, Maini S (2005) Accessing delayed and acute toxicity of five formulated fungicides to Osmia lignaria Say and Apis mellifera Linné. Apidologie 36: 449460. doi: 10.1051/apido:2005032

Lang A, Bühler C (2012) Estimation of required sampling effort for monitoring the possible effects of transgenic crops on butterflies: Lessons from long-term monitoring schemes in Switzerland. Ecological Indicators 13: 29-36. doi: 10.1016/j.ecolind.2011.05.004

Magnacca KN, Brown MJF (2012) DNA barcoding a regional fauna: Irish solitary bees. Molecular Ecology Resources 12 (6): 990-998. doi: 10.1111/1755-0998.12001

Malone LA, Burgess EPJ (2009) Impact of Genetically Modified Crops on Pollinators. In: Ferry N, Gatehouse AMR (Eds) Environmental impact of genetically modified crops. CAB International (Oxfordshire, UK): 199-224. doi: 10.1079/9781845934095.0199

Malone LA, Scott-Dupree CD, Todd JH, Ramankutty P (2007) No sublethal toxicity to bumblebees, Bombus terrestris, exposed to Bt-corn pollen, captan and novaluron. New Zealand Journal of Crop and Horticultural Science 35: 435-439. doi: 10.1080/01140670709510211

Meier MS, Hilbeck SA (2005) Faunistische Indikatoren für das Monitoring der Umweltwirkungen gentechnisch veränderter Organismen (GVO). Naturschutz und Biologische Vielfalt 29: 1-332.

Meissle M, Álvarez-Alfageme F, Malone LA, Romeis J (2012) Establishing a database of bio-ecological information on non-target arthropod species to support the environmental risk assessment of genetically modified crops in the EU. Supporting Publications EN-334. European Food Safety Authority (EFSA): 1-170. http://www.efsa.europa.eu/en/publications.htm

Michener CD (2007) The bees of the world. Second edition. The Johns Hopkins University Press (Baltimore): 1-953.

Morandin LA (2008) Genetically modified crops. Effects on bees and pollination. In: James R, Pitts-Singer T (Eds) Bee pollination in agricultural ecosystems. Oxford University Press (New York): 203-218. doi: 10.1093/acprof:oso/9780195316957.003.0012

Morandin LA, Winston ML (2003) Effects of novel pesticides on bumble bee (Hymenoptera:Apidae) colony health and foraging ability. Environmental Entomology 32: 555-563. doi: 10.1603/0046-225X-32.3.555

Morandin LA, Winston ML (2005) Wild bee abundance and seed production in conventional, organic, and genetically modified canola. Ecological Applications 15: 871-881. doi: $10.1890 / 03-5271$

Mühlenberg M (1993) Freilandökologie, 3. überarb. Aufl. Quelle \& Meyer (Wiesbaden): $1-512$.

Murray TE, Kuhlmann M, Potts SG (2009) Conservation ecology of bees: populations, species and communities. Apidologie 40: 211-236. doi: 10.1051/apido/2009015

Murray TE, Fitzpatrick Ú, Byrne A, Fealy R, Brown MJF, Paxton RJ (2012) Local-scale factors structure wild bee communities in protected areas. Journal of Applied Ecology: n/a-n/a. doi: $10.1111 / \mathrm{j} .1365-2664.2012 .02175 . x$ 
Osinski E, Meier U, Büchs W, Weickel J, Matzdorf B (2003) Application of biotic indicators for evaluation of sustainable land use-current procedures and future developments. Agriculture, Ecosystems und Environment 98: 407-421. doi: 10.1016/S0167-8809(03)00100-2 Plachter H (1991) Naturschutz. G. Fischer (Stuttgart):1-463.

Plachter H, Bernotat D, Müssner R, Riecken U (2002) Entwicklung und Festlegung von Methodenstandards im Naturschutz. Schriftenreihe für Landschaftspflege und Naturschutz 70: $1-566$.

Ricketts TH, Regetz J, Steffan-Dewenter I, Cunningham SA, Kremen C, Bogdanski A, Gemmill-Herren B, Greenleaf SS, Klein AM, Mayfield MM, Morandin LA, Ochieng' A, Viana B (2008) Landscape effects on crop pollination services: are there general patterns? Ecology Letters 11: 499-515. doi: 10.1111/j.1461-0248.2008.01157.x

Romeis J, Bartsch D, Bigler F, Candolfi MP, Gielkens MMC, Hartley SE, Hellmich RL, Huesing JE, Jepson PC, Layton R, Quemada H, Raybould H, Rose RI, Schiemann J, Sears MK, Shelton AM, Sweet J, Vaituzis Z, Wolt JD (2008) Assessment of risk of insect-resistant transgenic crops to nontarget arthropods. Nature Biotechnology 26: 203-208. doi: $10.1038 / \mathrm{nbt} 1381$

Roubik DW (1995) Pollination of cultivated plants in the tropics. FAO Agricultural Services Bulletin 118: 1-196.

Roulston TH, Goodell K (2011) The role of resources and risks in regulating wild bee populations. Annu. Rev. Entomol 56: 293-312. doi: 10.1146/annurev-ento-120709-144802

Saure C, Kühne S, Hommel B, Bellin U (2003) Transgener, herbizidresistenter Raps - Blütenbesuchende Insekten, Pollenausbreitung und Auskreuzung. Agrarökologie 44: 1-103.

Saure C, Berger G (2006) Flächenstilllegungen in der Agrarlandschaft und ihre Bedeutung für Wildbienen. - Naturschutz und Landschaftspflege in Brandenburg 15 (2): 55-65.

Schindler M, Wittmann D (2011) Auswirkungen des Anbaus vielfältiger Fruchtfolgen auf wirbellose Tiere in der Agrarlandschaft. Feldstudien an Blütenbesuchern und Bodenarthropoden. Landwirtschaftliche Fakultät der Universität Bonn. Schriftenreihe des Lehr- und Forschungsschwerpunktes USL 167: 1-80.

Schmid-Egger C (1994) Die Eignung von Stechimmen (Hymenoptera: Aculeata) zur naturschutzfachlichen Bewertung am Beispiel der Weinbergslandschaft im Enztal und im Stromberg (nordwestliches Baden-Württemberg). Cuvillier (Göttingen): 1-230.

Schwenninger HR (1992) Untersuchungen zum Einfluß der Bewirtschaftungsintensität auf das Vorkommen von Insektenarten in der Agrarlandschaft, dargestellt am Beispiel der Wildbienen (Hymenoptera: Apoidea). Zool. Jb. Syst. 119: 543-561.

Schwenninger HR (1994) Qualitätskriterien von Wildbienengutachten im Rahmen von landschaftsökologischen Untersuchungen. UVP-Report 5/94: 301-302.

Sepp K, Mikk M, Mänd M, Truu J (2004) Bumblebee communities as an indicator for landscape monitoring in the agri-environmental programme. Landscape and Urban Planning 67: 173-183. doi: 10.1016/S0169-2046(03)00037-9

Steffan-Dewenter I (1998) Wildbienen in der Agrarlandschaft: Habitatwahl, Sukzession, Bestäubungsleistung und Konkurrenz durch Honigbienen. Agrarökologie 27. Verlag Agrarökologie (Hannover): 1-134. 
Stephen WP, Rao S (2005) Unscented colour traps for non-Apis bees (Hymenoptera: Apiformes). Journal of the Kansas Entomological Society 78: 373-380. doi: 10.2317/0410.03.1 Steyskal GC, Murphy WL, Hoover EM (Eds) (1986) Insects and mites: Techniques for collection and preservation. U.S. Department of Agriculture. Misc. Pubs. 1443: 1-103.

Sutherland WJ (2010) Ecological census techniques. Second Edition. University Press (Cambridge): $1-448$.

Thompson H (2003) Behavioural effects of pesticides in bees - their potential for use in risk assessment. Ecotoxicology 12: 317-330. doi: 10.1023/A:1022575315413

Tscharntke T, Gathmann A, Steffan-Dewenter I (1998) Bioindication using trap nesting bees and wasps and their natural enemies: community structure and seed set. J. Appl. Ecol. 35: 708-719. doi: 10.1046/j.1365-2664.1998.355343.x

Tscharntke T, Klein AM, Kruess A, Steffan-Dewenter I, Thies C (2005) Landscape perspectives on agricultural intensification and biodiversity - ecosystem service management. Ecology Letters 8: 857-874. doi: 10.1111/j.1461-0248.2005.00782.x

Tuell JK, Isaacs R (2010) Community and species-specific responses of wild bees to insect pest control programs applied to a pollinator-dependent crop. J. Econ. Entomol. 103 (3): 668-675. doi: 10.1603/EC09314

Walther-Hellwig K, Frankl R (2000) Foraging habitats and foraging distances of bumblebees, Bombus spp. (Hym., Apidae), in an agricultural landscape. Journal of Applied Entomology 124: 299-306. doi: 10.1046/j.1439-0418.2000.00484.x

Weber K (1999) Ausgewählte Hautflügler: Wildbienen. In: Vereinigung Umweltwissenschaftlicher Berufsverbände Deutschlands e.V. (Ed) Handbuch landschaftsökologischer Leistungen. Empfehlungen zur aufwandsbezogenen Honorarermittlung. 3. Auflage, Selbstverlag (Nürnberg): 231-239.

Westphal C, Bommarco R, Carre G, Lamborn E, Morison N, Petanidou T, Potts, SG, Roberts SPM, Szentgyörgyi H, Tscheulin T, Vaissiere BE, Woyciechowski M, Biesmeijer JC, Kunin WE, Settele J, Steffan-Dewenter I (2008) Measuring bee diversity in different European habitats and biogeographical regions. Ecological Monographs 78: 653-671. doi: 10.1890/07-1292.1

Westrich P (1989) Die Wildbienen Baden-Württembergs. Ulmer (Stuttgart): 1-972.

Westrich P (1996) Habitat requirements of central European bees and the problems of partial habitats. In: Matheson A, Buchmann SL, O’Toole C, Westrich P, Willliams IH (Eds) The Conservation of Bees, Academic Press (London): 1-16.

Westrich P, Frommer U, Mandery K, Riemann H, Ruhnke H, Saure C, Voith J (2012) Rote Liste und Gesamtartenliste der Bienen (Hymenoptera, Apidae) Deutschlands (5. Fassung, Stand Februar 2011). In: Bundesamt für Naturschutz (Hrsg.): Rote Liste gefährdeter Tiere, Pflanzen und Pilze Deutschlands. Band 3: Wirbellose Tiere (Teil 1). Naturschutz und biologische Vielfalt 70: 373-416.

Whitehorn PR, O'Connor S, Wackers FL, Goulson D (2012) Neonicotinoid pesticide reduces bumblebee colony growth and queen production. Science 336 (6079): 351-352. doi: $10.1126 /$ science. 1215025

Williams IH, Carreck NL (1994) Land use changes and honey bee forage plants. In Matheson A (Ed) Forage for bees in an agricultural landscape. IBRA (Cardiff): 8-20. 
Zurbuchen A, Müller A (2012) Wildbienenschutz - Von der Wissenschaft zur Praxis. BristolStiftung Zürich. Haupt (Bern): 1-162.

Zurbuchen A, Cheesman S, Klaiber J, Müller A, Hein S, Dorn S (2010a) Long foraging distances impose high costs on offspring production in solitary bees. Journal of Animal Ecology 79: 674-681. doi: 10.1111/j.1365-2656.2010.01675.x

Zurbuchen A, Landert L, Klaiber J, Müller A, Hein S, Dorn S (2010b) Maximum foraging ranges in solitary bees: only few individuals have the capability to cover long foraging distances. Biological Conservation 143: 669-676. doi: 10.1016/j.biocon.2009.12.003 